\title{
Neoadjuvant Radiochemotherapy for Patients with Locally Advanced Esophagogastric Junction Adenocarcinoma
}

\author{
Cristian Daniel Marica', Rodica Bîrlă', Raluca Marica', Eugenia Panaitescu'², Silviu Constantinoiu' \\ "'Carol Davila" University of Medicine and Pharmacy, General and Esophageal Surgery Clinic, \\ Center of Excellence in Esophageal Surgery, Sf. Maria Clinical Hospital, Bucharest, Romania \\ "Carol Davila" University of Medicine and Pharmacy, Department of Informatics and Biostatistics, Bucharest, Romania
}

Corresponding author:

Cristian Daniel Marica, MD

"Carol Davila" University of Medicine and Pharmacy, General and Esophageal Surgery Clinic, Center of Excellence in Esophageal Surgery, Sf. Maria Clinical Hospital, Bucharest, Romania E-mail: Marica_cd@yahoo.com

\section{Rezumat}

Radiochimioterapia neoadjuvantă la pacientii cu adenocarcinom de jonctiune esogastrică avansat local

Radiochimioterapia (RCT) neoajuvantã reprezintã o modalitate de management acceptatã de multe centre în abordarea adenocarcinomului de joncåiune esogastricã (JEG) avansat local Scopul: Influența RCT neoadjuvante asupra rezultatelor postoperatorii imediate şi la distanță la pacienții cu adenocarcinoame de JEG avansate local.

Metoda: În Centrul de Excelență în Chirurgia Esofagiană de la Spitalul Sfânta Maria între 2010-2017 au fost tratați 62 pacienți cu adenocarcinoame de JEG avansate local. Conform clasificării Siewert si Stein lotul a cuprins tipul I - 11 pacienti, tipul II - 18 pacienți şi tipul III - 33 pacienți. Radichimioterapie neoadjuvantă au efectuat 17 pacienți. Tratamentul chirurgical la cei 62 de pacienți rezecați a fost: esogastrectomie totală pe cale abdominală - 40 pacienți, esofagectomie subtotală cu rezecția micii curburi gastrice - 13 pacienți, esofagectomie subtotală prin triplu abord McKeown - 5 pacienți şi esofagectomie abdomino-cervicală Orringer - 4 pacienti.

Rezultate: Morbiditatea postoperatorie a fost de $46,77 \%$ şi a fost reprezentată în principal de fistule la 17 pacienți şi complicatii pulmonare de tipul pleureziilor, pneumoniilor si sindromului de detresă respiratorie la 12 pacienți. S-au constatat fistule la 15 pacienti: gradul $1-2$ pacienti, gradul $2-10$ pacienti, gradul $3-5$ pacienti. Mortalitatea postoperatorie a fost de $4.8 \%$. (p_value $=$ 0.017980 Fisher's Exact Test). Regresia stadiului inițial s-a intâlnit 
la 7 pacienți. Nu am întâlnit diferențe semnificativ statistice în ceea ce priveşte supraviețuirea la distantă.

Concluzii: RCT neoadjuvantă nu a avut un impact asupra morbidității postoperatorii, dar a influențat semnificativ statistic mortalitatea postoperatorie.

Cuvinte cheie: radiochimioterapie neoadjuvantă, adenocarcinom de joncțiune

\section{Abstract}

Scope: neoadjuvant RCT influence on early and long term postoperative outcomes in patients with locally advanced esophagogastric junction adenocarcinomas.

Materials and Method: Sixty two patients with locally advanced esophagogastric junction adenocarcinomas were treated at the Center of Excellence in Esophageal Surgery at St. Mary Hospital between 2010-2017. According to the Siewert classification, the group comprised of type I - 11 patients, type II - 18 patients and type III - 33 patients. Only 17 patients received preoperative RCT. The surgical treatment for the 62 resected patients was: abdominal extended gastrectomy - 40 patients, Ivor-Lewis - 13 patients, McKeown esophagogastrectomy (3 incisions) - 5 patients and transhiatal esophagectomy - 4 patients.

Results: Postoperative morbidity was $46.77 \%$ and was mainly represented by fistulas in 17 patients and pulmonary complications such as pleurisy,pneumonia and ARDS in 12 patients. Fistula occurred in 15 cases: grade 1 - 2 patients, grade 2 - 10 patients, grade $3-5$ patients. Postoperative mortality was $4.8 \%$ (p_value $=0.017980$ Fisher's Exact Test). Downstaging was observed in 7 patients. I did not encounter statistically significant differences in long term survival.

Conclusions: Neoadjuvant RCT had no impact on postoperative morbidity, but statistically influenced postoperative mortality.

Key words: neoadjuvant radiochemoterapy, esophagogastric adenocarcinoma

\section{Introduction}

Adenocarcinomas of esophageal junction have an increasing incidence lately, especially in western countries and unlike Asia, in these countries the presentation is delayed and usually it's in an advanced stage. Currently, there is no consensus regarding the management of patients with advanced local esophagogastric junction adenocarcinomas. If there is unanimity for Siewert I tumors regarding surgical technique, for Siewert II and III tumors there is still a matter of debate regarding surgical approach, operative risks that may occur and the postoperative complications (1).

An important factor to be taken into account after junction adenocarcinomas surgery is the risk of fistula (somewhere between 10-15\%) and the complications that may occur with it $(2,3)$.
Between 1996 and 2013, there have been numerous studies of chemotherapy or chemotherapy associated with preoperative radiotherapy, which concluded that neoadjuvant radiochemotherapy (and even chemotherapy alone) leads to a better postoperative outcome and longer survival for patients with advanced tumor stage comparative with surgical treatment only. According to several studies, neoadjuvant RCT can act on both microadenopathies and primary tumors, increasing the chance of complete resection and, in some cases, achieving a complete pathological response $(4,5)$.

\section{Materials and Method}

A retrospective study was conducted on a group of 62 patients with locally advanced 
esophagogastric junction adenocarcinomas that received surgery at St. Mary Clinical Hospital in Bucharest, at the Center of Excellence in Esophageal Surgery, between January 2010 and December 2017.

The group consisted of 45 men and 17 women with average age of 64 . These were assessed using common investigation methods such as oespphagogastroduodenoscopy (OGD) with biopsy, barium meal, ultrasound and computerized tomography, but endoscopic ultrasound (EUS) and PET-CT were also used for a limited number of patients. The preoperative allocation into Siewert classification was based mainly on the correlation of the endoscopic location of tumor with the radiological aspect (Fig.1).

According to the Siewert classification, the group comprised of type I - 11 patients, type II 18 patients and type III - 33 patients. Neoadjuvant RCT was indicated for 17 patients.

The proposed preoperative treatment was radiotherapy $41.4-50.4$ Gy (1.8-2.0Gy/d) with concurrent chemotherapy (fluoropyrimidines and oxaliplatin usual regimen, modified or adjusted in case of toxicity). The gross target volume included the regional lymph nodes identified at $\mathrm{CT}$ togheter with the clinical target volume (CTV) which is the primary tumor plus $3-4 \mathrm{~cm}$ superior and inferior and $1 \mathrm{~cm}$ lateral.

After preoperative treatment, the patients

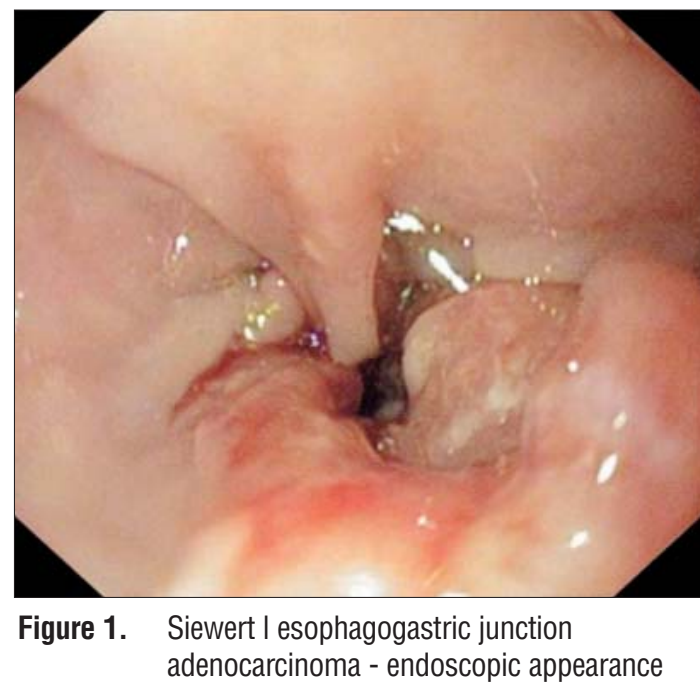

were endoscopically, tomographically and radiologically assessed regarding response to treatment (Fig. 2).

The surgical treatment of these patients was, depending on the location of the tumor, according to the Siewert classification, by subtotal esophagectomy with lymphadenectomy on 1,2 or 3 fields. The technique applied to the 62 patients was: abdominal extended gastrectomy in 40 patients, subtotal esophagectomy with resection of lesser curvature - Ivor Lewis procedure in 13 patients, esophagectomy McKeown approach (3 incisions) in 5 patients and transhiatal esophagectomy (Orringer procedure) in 4 patients.

The abdominal approach of Siewert type III tumors was performed by abdominal medial incision and a dissection of the lower thoracic esophagus transhiatally (Hill technique) (Fig. 3).

The Ivor-Lewis esophagectomy is combining the abdominal approach with the right thoracotomy and offers the possibility of a better dissection of the mediastinal lymph nodes, but at the same time it is a technique in which the anastomosis of the esophagus is placed in the thorax (Fig. 4).

Another technique used was abdominal, thoracic and cervical esophagectomy, the McKeown technique (3 incisions). This adds a left cervical incision for anastomosis, placing it at the cervical level, thus avoiding major

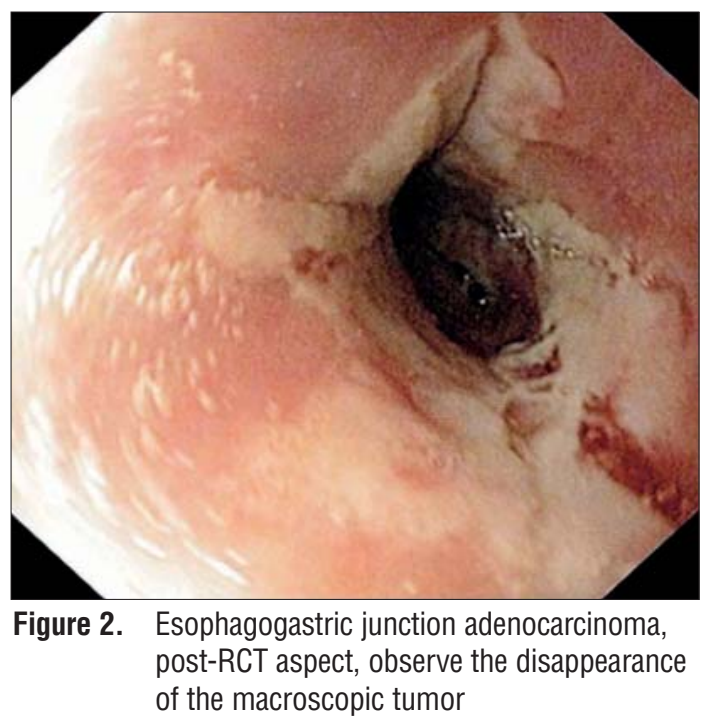




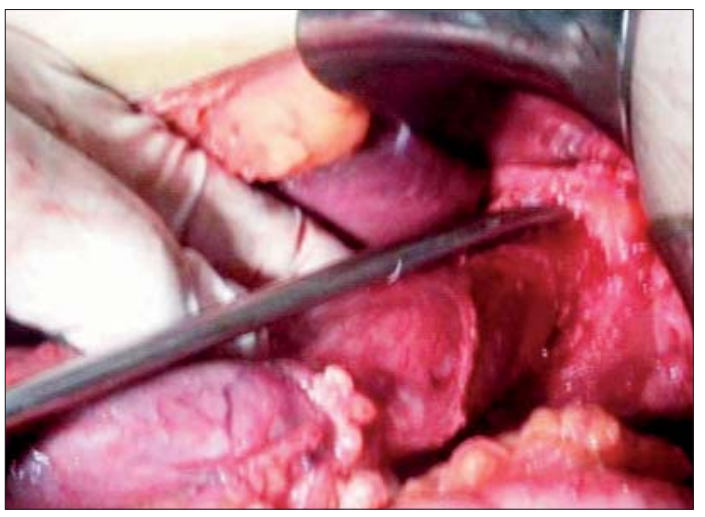

Figure 3. Excision of lower esophagus through transhiatal dissection

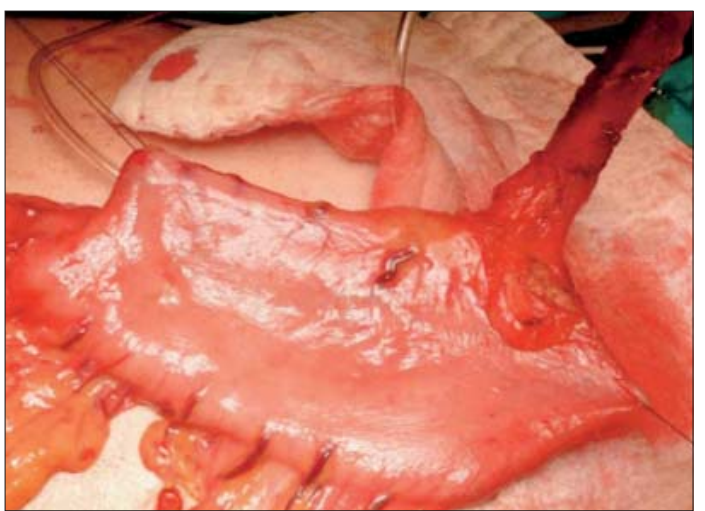

Figure 5. McKeown esophagectomy, distal resection limits

complications and providing the possibility of easier treatment of the fistula.

The transhiatal approach (Orringer), which involves a medial abdominal incision and a cervical incision, has a cervical anastomosis between remaining esophagus and tubulized stomach (Fig. 7), this technique having the advantages of lower postoperative thoracic complications than the transthoracic approach, but cervical anastomosis presents a higher risk of fistula according to numerous studies.

Anastomoses were hand sewed in 23 patients, mainly interrupted absorbable sutures of Maxon 3-0, circular mechanical anastomoses were also performed in 39 patients, especially in the case of abdominal Hill approach, where manual anastomosis is

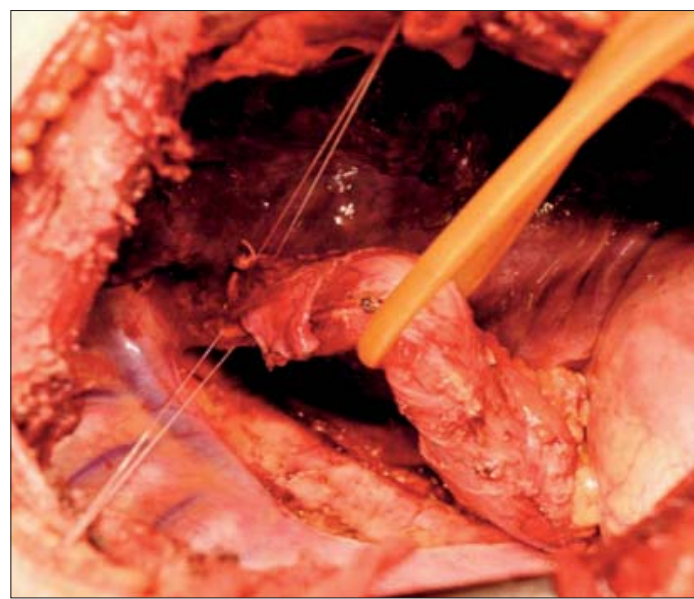

Figure 4. Flvor Lewis resection for esophagogastric junction adenocarcinoma, setting the esophageal resection limit

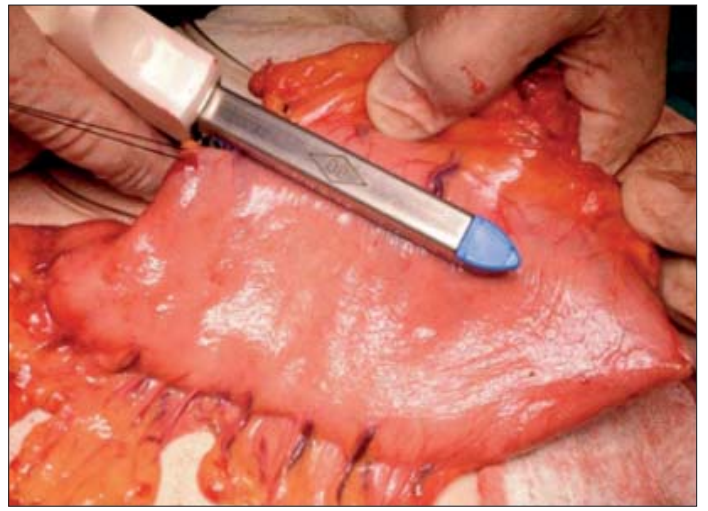

Figure 6. McKeown esophagectomy, tubulisation of stomach

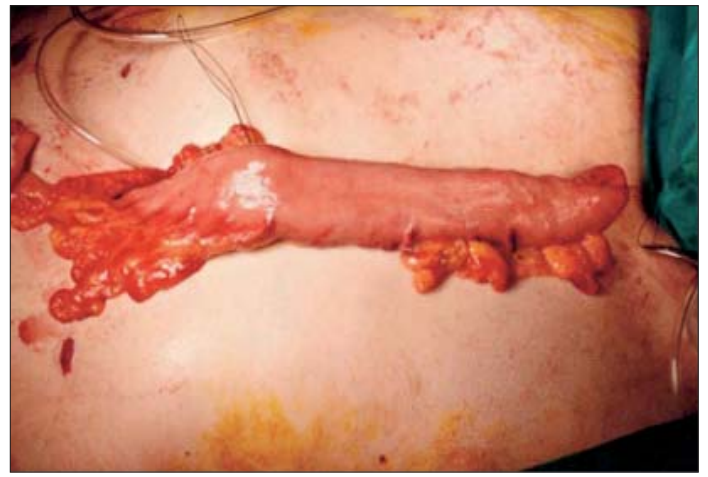

Figure 7. Transhiatal esophagectomy (Orringer) - tubulized stomach ready to be passed into the neck, length check

performed with high difficulty or transthoracic approach due to the vital risk of anastomotic fistula with this localization. Anastomotic 


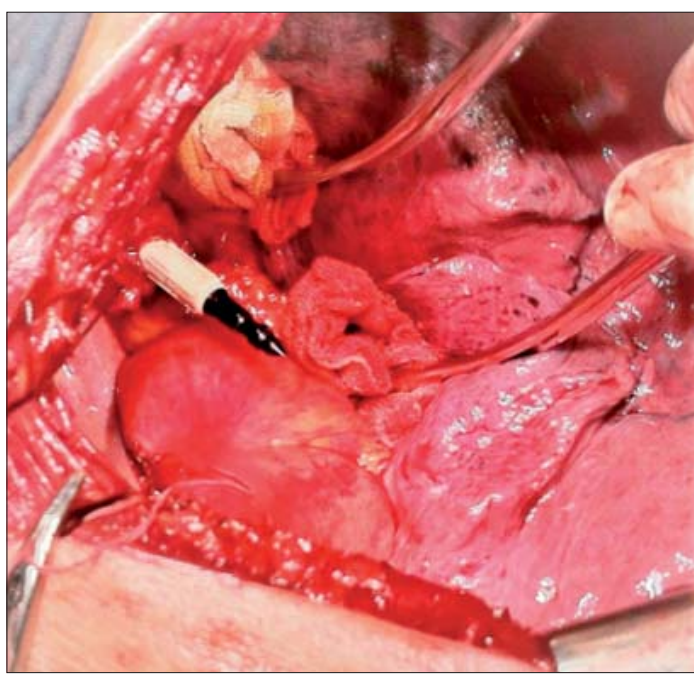

Figure 8. Thoracic anastomosis - the anvil is placed inside the esophageal lumen

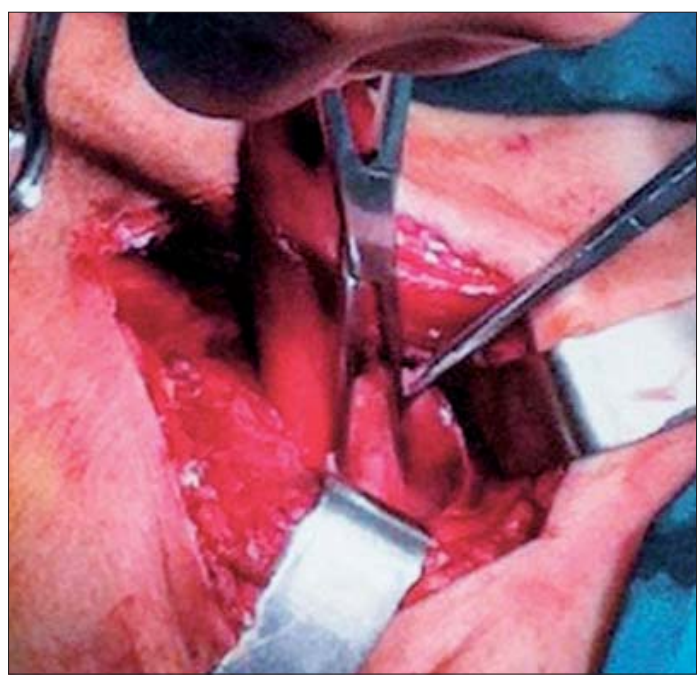

Figure 9. Cervical anastomosis - esophagus on the left and stomach on the right

There were no statistically significant differences between patients that received and those who did not received neoadjuvant radiotherapy in the incidence of anastomotic fistula or pulmonary complications. Also no statistically significant differences between the two groups of patients were observed in fistula incidence by reference to the 2015 Esofagectomy Complications Consensus Group (ECCG).

Postoperative mortality was $4.8 \%$ - 3 patients died in the neoadjuvant RCT group one due to lung complications, one of sepsis following a grade 3 fistula and one by decompensated hepatic cirrhosis in postoperative day 3.

Data processing revealed a statistically significant difference in postoperative mortality in the two groups of patients. Neoadjuvant RCT significantly influenced postoperative mortality.

All patients in the batch were operated and

Table 1. Correlation of Postoperative Morbidity with Neoadjuvant RCT - Statistical Data Processing

\begin{tabular}{llll}
\hline & PreRCT=Yes $(\mathbf{N}=17)$ & PreRCT=No $(\mathbf{N}=45)$ & p_value (test) \\
\hline Fistula=yes & $4 / 17(23.5 \%)$ & $13 / 45(28.9 \%)$ & 0.759385 (Fisher's Exact Test) \\
\hline Fistula_grade & & & 0.070003 (Likelihood Ratio) \\
1 & $0 / 4(0.0 \%)$ & $2 / 13(15.4 \%)$ & \\
2 & $1 / 4(25.0 \%)$ & $9 / 13(69.2 \%)$ & \\
3 & $3 / 4(75.0 \%)$ & $2 / 13(15.4 \%)$ & 0.155311 (Fisher's Exact Test) \\
\hline Lung complications & $12 / 17(70.6 \%)$ & $39 / 45(86.7 \%)$ & \\
\hline
\end{tabular}


Table 2. Correlation of postoperative mortality with neoadjuvant RCT - Statistical data processing

\begin{tabular}{lccc}
\hline & PreRCT $=$ Yes $(\mathbf{N}=\mathbf{1 7})$ & PreRCT $=$ No $(\mathbf{N}=\mathbf{4 5})$ & P_value (test) \\
\hline Postoperative Death & $3 / 17(17.6 \%)$ & $0 / 45(4.4 \%)$ & 0.017980 (Fisher's Exact Test) \\
\hline
\end{tabular}

the resected specimens were examined histopathologically. Microscopically features evaluated: $\mathrm{pT}, \mathrm{pN}, \mathrm{pM}$, and ypT, ypN, ypM for patients that received neoadjuvant RCT.

We have noticed a significant difference in ratio between $\mathrm{pT}$ and $\mathrm{yp} \mathrm{T}$ category $\left(\mathrm{p} \_\right.$value $=$ 0.015274, Likelihood Ratio) of the ones that received preoperative $\mathrm{RCT}$ and the other group who did not, as follows: for T0 category (pTNM), between those with preoperative treatment (11.8\%) and those without (0.0\%) - 2 patients with neoadjuvant RCT had no residual tumor; and for T2 category (pTNM) between those with preoperative treatment $(35.3 \%)$ and those without (8.9\%) - patients that did not received preoperative RCT had a deeper parietal tumor invasion compared with the ones that received chemoradiation. In the neoadjuvant RCT group no $\mathrm{T} 4$ category tumors were reported.

We found a significant difference between ypTNM stage for patients with neoadjuvant $\mathrm{RCT}$ and $\mathrm{pTNM}$ stage for patients that undergo surgery first (p_value $=0.000117$, Likelihood Ratio), as follow: stage II pTNM between preoperative RCT (40.0\%) and no preoperative $\mathrm{RCT}(0.0 \%)$ - postoperative stage ypTNM showed that 7 patients with neoadjuvant RCT were found in stage I (1 patient) and II (6 patients), even though these patients had locally advanced tumors at baseline.

A statistically significant difference was also observed by comparing the number of metastatic lymph nodes between the two groups of patients (p_value $=0.004461$ Mann $^{-}$ Whitney Test). Invaded lymph nodes found were significantly less in number following neoadjuvant RCT.

Median follow up for patients was 35,5 months. On January 1, 2018, 9 patients out of 17 patients with preoperative chemoradiation and 24 out of 45 patients without RCT, were surviving.

There was no significant difference in the statistical analysis of deceased patients.

Survival Analysis - Neoadjuvant RCT

Table 3. Correlation of pathological criteria pT, pN, pM or ypT, ypN, ypM for - statistical data processing

\begin{tabular}{llll}
\hline pTNM_T & & & $\mathbf{0 . 0 1 5 2 7 4}$ (Likelihood Ratio) \\
\hline 0 & $2 / 17(11.8 \%)$ & $0 / 45(0.0 \%)$ & \\
1 & $0 / 17(0.0 \%)$ & $1 / 45(2.2 \%)$ & \\
2 & $6 / 17(35.3 \%)$ & $4 / 45(8.9 \%)$ & \\
3 & $9 / 17(52.9 \%)$ & $33 / 45(73.3 \%)$ & \\
4 & $0 / 17(0.0 \%)$ & $4 / 45(8.9 \%)$ & \\
$4 \mathrm{a}$ & $0 / 17(0.0 \%)$ & $2 / 45(4.4 \%)$ & \\
$4 \mathrm{~b}$ & $0 / 17(0.0 \%)$ & $1 / 45(2.2 \%)$ & $\mathbf{0 . 0 5 6 8 7 3}$ (Likelihood Ratio) \\
\hline pTNM_N & & & \\
\hline 0 & $8 / 17(47.1 \%)$ & $8 / 45(17.8 \%)$ & \\
1 & $1 / 17(5.9 \%)$ & $13 / 45(28.9 \%)$ & \\
2 & $2 / 17(11.8 \%)$ & $10 / 45(22.2 \%)$ & \\
3 & $1 / 17(5.9 \%)$ & $5 / 45(11.1 \%)$ & \\
$3 \mathrm{a}$ & $0 / 17(0.0 \%)$ & $6 / 45(13.3 \%)$ & \\
3b & $0 / 17(0.0 \%)$ & $3 / 45(6.7 \%)$ & $\mathbf{0 . 1 9 7 3 0 9}$ (Likelihood Ratio) \\
\hline pTNM_M & & & \\
\hline 0 & $16 / 17(94.1 \%)$ & $44 / 45(97.8 \%)$ & \\
1 & $0 / 17(0.0 \%)$ & $1 / 45(2.2 \%)$ & \\
$1 \mathrm{a}$ & $1 / 17(5.9 \%)$ & $0 / 45(0.0 \%)$ & \\
\hline
\end{tabular}


Table 4. Correlation of pathological staging PTNM or ypTNM with preoperative RCT - statistical data processing

\begin{tabular}{llll}
\hline & $\begin{array}{l}\text { PreRCT.=Yes } \\
(\mathbf{N}=17)\end{array}$ & $\begin{array}{l}\text { PreRCT=No } \\
(\mathbf{N}=45)\end{array}$ & p_value (test) \\
\hline pTNM Stage & & & \\
\hline I & $1 / 15(6.7 \%)$ & $0 / 44(0.0 \%)$ & \\
II & $6 / 15(40.0 \%)$ & $0 / 44(0.0 \%)$ & \\
IIA & $0 / 15(0.0 \%)$ & $5 / 44(11.4 \%)$ & \\
IIB & $1 / 15(6.7 \%)$ & $12 / 44(27.3 \%)$ & \\
IIIA & $2 / 15(13.3 \%)$ & $10 / 44(22.7 \%)$ & \\
IIIB & $4 / 15(26.7 \%)$ & $10 / 44(22.7 \%)$ & \\
IIIC & $0 / 15(0.0 \%)$ & $6 / 44(13.6 \%)$ & \\
IV & $1 / 15(6.7 \%)$ & $1 / 44(2.3 \%)$ & 0.000117 (Likelihood Ratio) \\
\hline
\end{tabular}

Table 5. Correlation of dissected lymph nodes and metastatic lymph nodes with neoadjuvant RCT - statistical data processing

\begin{tabular}{llll}
\hline & $\begin{array}{l}\text { PreRCT }=\text { Yes } \\
(\mathbf{N}=\mathbf{1 7})\end{array}$ & $\begin{array}{l}\text { PreRCT=No } \\
(\mathbf{N}=\mathbf{4 5})\end{array}$ & p_value (test) \\
\hline Lymph Nodes Total & $15.00 \pm 7.4475$ & $15.13 \pm 7.3345$ & 0.949642 \\
& $15.5[8.0,20.0]$ & $14.0[10.0,18.7]$ & (Independent Samples T Test) \\
\hline Positive Lymph Nodes & $1.75 \pm 2.2360$ & $6.27 \pm 7.1799$ & 0.004461 \\
& $1.5[0.0,2.7]$ & $4.0[1.0,9.7]$ & (Mann-Whitney Test) \\
\hline
\end{tabular}

Influence on overall survival - Statistical Data Processing

Survival analysis shows similar survival curves. However, 5 years survival in patients with neoadjuvant RCT was $0 \%$ while for patients without neoadjuvant RCT 5 years survival rate was $50.9 \%$. a. Estimation is limited to the largest survival time if it is censored.

Overall survival comparison at $6,12,18,24$, 36, 48, 60 months between preoperative RCT group and no preoperative RCT group did not show statistically significant differences.

Table 6. Correlation of long term survival with neoadjuvant RCT - Statistical Data Processing

\begin{tabular}{llll}
\hline & $\begin{array}{l}\text { PreRCT=Yes } \\
(\mathbf{N}=17)\end{array}$ & $\begin{array}{l}\text { PreRCT=No } \\
(\mathbf{N}=45)\end{array}$ & P_value (test) \\
\hline Death & $8 / 17(47.1 \%)$ & $21 / 45(46.7 \%)$ & $\begin{array}{l}1.000000 \\
\text { (Fisher's Exact Test) }\end{array}$ \\
\hline
\end{tabular}

Table 7. Case Processing Summary

\begin{tabular}{lcccc}
\hline PreRCT & Total N & N of Events & \multicolumn{2}{c}{ Censored (Surviving) } \\
\hline & & & N & Percent \\
\hline da & 17 & 8 & 9 & $52.9 \%$ \\
\hdashline nu & 45 & 21 & 24 & $53.3 \%$ \\
\hline Overall & 62 & 29 & 33 & $53.2 \%$ \\
\hline
\end{tabular}

Table 8. Overall Comparisons

\begin{tabular}{llll}
\hline & Chi-Square & df & Sig. (p_value) \\
\hline Log Rank (Mantel-Cox) & .891 & 1 & 0.345 \\
\hline Breslow (Generalized Wilcoxon) & .557 & 1 & 0.456 \\
\hline
\end{tabular}

Test of equality of survival distributions for the different levels of Preirad 


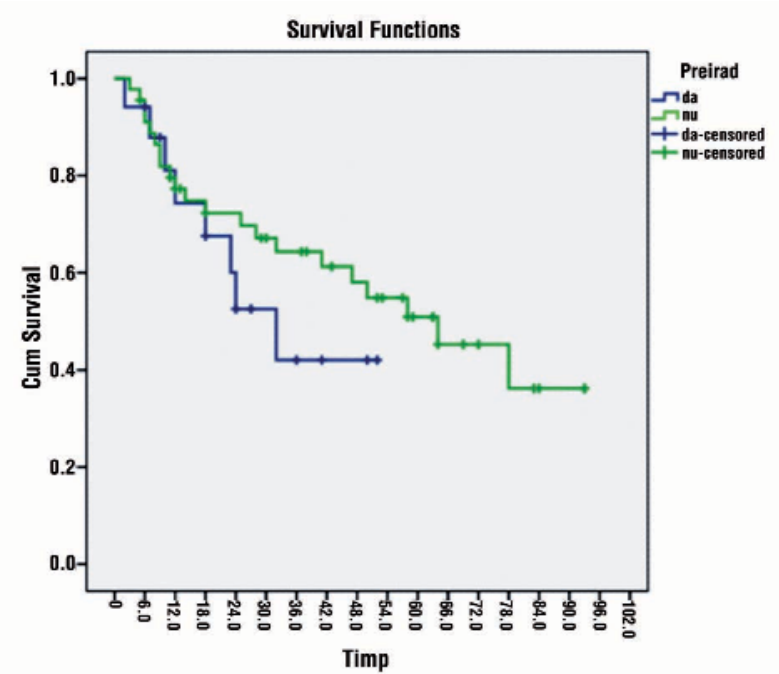

Figure 10. Kaplan Meier survival curves test by neoadjuvant RCT(yes or no)

\section{Discussions}

Despite the increased incidence of gastroesophageal junction adenocarcinoma in western countries (6), the optimal therapeutic protocol for locally advanced disease remains controversial. There is a poor outcome with surgery as the only therapeutic way. Multimodal therapy improves survival, but there is a lack of consensus regarding clinical approach throughout the world.

Many literature data suggest that preoperative chemotherapy or chemoradiation offers better results compared to surgery alone for esophagogastric junction adenocarcinoma $(7,8)$. Patients with locally advanced tumors benefit from neoadjuvant therapy compared to surgery only (9).

Neoadjuvant chemotherapy is better tolerated than adjuvant therapy and therefore dose level established is likely to be maintained in a higher number of patients. Also, neoadjuvant treatment can induce tumor downstaging, raising the possibility of complete surgical resection. This may be particularly important in western populations because these patients often have more advanced tumors than Asian patients (10).

Despite adequate resection, a significant number of patients with esophagogastric adenocarcinoma relapse locally (11). Preoperative chemoradiation can reduce local recurrences and improve overall pathological response rates, a variable associated with improved survival (11-13).

Because many patients after esophagogastrectomy fail to recover to the point of tolerability for postoperative therapy, chemoradiotherapy for esophanogastric junction tumors is rarely applied $(14,15)$.

In the studied group 17 of the patients included received neoadjuvant RCT, the remaining patients had surgery first, the complementary treatment being indicated in accordance with the histopathological criteria of the resection specimen. The neoadjuvant $\mathrm{RCT}$ at the dose of $45-50.4$ Gy in 25-28

Table 9. Means and Medians for Survival Time

\begin{tabular}{|c|c|c|c|c|c|c|c|c|}
\hline \multirow[t]{3}{*}{ Preop RCT } & \multicolumn{4}{|c|}{ Meana } & \multicolumn{4}{|c|}{ Median } \\
\hline & \multirow[t]{2}{*}{ Estimate } & \multirow[t]{2}{*}{ Std. Error } & \multicolumn{2}{|c|}{ 95\% Confidence Interval } & \multirow[t]{2}{*}{ Estimate } & \multirow[t]{2}{*}{ Std. Error } & \multicolumn{2}{|c|}{ 95\% Confidence Interval } \\
\hline & & & Lower Bound & Upper Bound & & & Lower Bound & Upper Bound \\
\hline Yes & 32.015 & 4.932 & 22.349 & 41.681 & 32.000 & 7.067 & 18.148 & 45.852 \\
\hline No & 55.798 & 5.729 & 44.570 & 67.026 & 64.000 & 13.069 & 38.386 & 89.614 \\
\hline Overall & 53.143 & 5.067 & 43.213 & 63.074 & 58.000 & 12.128 & 34.229 & 81.771 \\
\hline
\end{tabular}

Table 10.

\begin{tabular}{lccccccc}
\hline Survival & $\mathbf{6}$ months & $\mathbf{1 2}$ months & $\mathbf{1 8}$ months & $\mathbf{2 4}$ months & $\mathbf{3 6}$ months & $\mathbf{4 8}$ months & $\mathbf{6 0}$ months \\
\hline PreRCT $=$ Yes & $94.1 \%$ & $74.3 \%$ & $67.6 \%$ & $52.6 \%$ & $42.0 \%$ & $42.0 \%$ & - \\
\hline PreRCT $=$ No & $91.0 \%$ & $77.3 \%$ & $72.3 \%$ & $72.3 \%$ & $64.3 \%$ & $58.1 \%$ & $50.9 \%$ \\
\hline
\end{tabular}


fractions was commonly the recommended dose for the control of microscopic disease.

Postoperative morbidity was $40 \%$ compared to the literature that revealed lower morbidity (around 17.9\%). In the group with neoadjuvant RCT, there was no statistically significant difference in postoperative morbidity. RCT did not influenced the occurrence of anastomotic fistula or it's severity, nor the pulmonary complications, comparable to some published studies (16).

Tumor regression was noticed in 7 patients after initial chemoradiation and increased numbers of T1-T2 tumors in the group compared with the monotherapy group $(41 \%$ vs. 0\%) compared to other literature data. (17)

Radiochemotherapy significantly improved complete pathological response rate $(17 \%)$ compared to other studies (15.6\% versus $2.0 \%$, $\mathrm{p}=0.03$, respectively, $29 \%$ complete pathological response rate) and significantly decreased the number of metastatic lymph nodes $(p=0.004)$, also supported by other literature studies $(17,18)$.

Mortality was $4.8 \%$ similar to other literature data. All patients in the neoadjuvant RCT lot determined a statistically significant difference in postoperative mortality, unlike some literature data showing that neoadjuvant RCT did not influence postoperative mortality (16).

There was no statistically significant difference in the long-term survival curves among the lot of patients with neoadjuvant RCT versus those who did not received RCT.

Similar data are reported by Urba et al. (19) who did not notice any survival advantage in preoperative radiochemoterapy patients, probably due to insufficient statistical power. A larger Australian Phase III study ( $=265)$, which included gastroesophageal junction tumors, reported a significantly better rate of $\mathrm{R} 0$ resection after radiochemotherapy ( $80 \%$ vs. $59 \%, p=.0002)$, but without improvement of overall survival or disease free survival (20).

In contrast to our results, many literature data suggest that mean global survival was significantly higher in those with RCT and surgery than in the surgical only group (49.4 months vs. 24.0 months). The results were better for preoperative RCT and surgery for 3 year survival (47.4\% vs. 2.7\%) (21).

Walsh et al. showed a net improvement in survival after multimodal therapy (global survival at 3 years of $32 \%$ vs. $6 \%, p=.01$ )

An justification for the results obtained may be the small number of patients included in the study group and the fact that patients who did not received neoadjuvant RCT followed a postoperative treatment, unlike other study groups where surgery was the only therapy.

We strongly agree with literature data that patients who underwent an esophagogastrectomy resection and have lymph node metastases on the resection specimen require some form of adjuvant treatment (22).

There are authors who consider that patients with esophagogastric junction adenocarcinomas are more susceptible to develop distant disease and therefore a systemic approach to chemotherapy can be more beneficial than an localized only treatment strategy for these patients (23).

Long-term follow-up of esophagogastric junction adenocarcinoma patients validate the overall survival benefits of neoadjuvant chemoradiotherapy. This improvement is clinically relevant for both squamous carcinoma and adenocarcinoma subtypes $(24,25)$.

Neoadjuvant radiochemotherapy can lead to tumor regression, decreased incidence of local recurrence, and improved overall survival of patients. A therapeutic strategy that includes neoadjuvant radiochimioterapy should be implemented in clinical practice for the treatment of locally advanced esophagogastric junction adenocarcinomas $(26,27)$.

\section{Conclusions}

Neoadjuvant RCT did not statistically influence postoperative morbidity as opposed to postoperative mortality.

Preoperative treatment RCT determined regression of the $\mathrm{cT}$ and $\mathrm{cN}$ criteria and the cTNM stage. Overall survival of patients with neoadjuvant RCT was similar with that of patients with surgical treatment and postoperative adjuvant chemotherapy. 


\section{Authors' Contributions}

All authors has equal contributions.

\section{Conflict of Interests}

The authors declare no conflict of interests.

\section{References}

1. Reynolds JV, Preston SR, O'Neill B, Baeksgaard L, Griffin SM, Mariette C, et al. ICORG 10-14: NEOadjuvant trial in Adenocarcinoma of the oEsophagus and oesophagoGastric junction International Study (NeoAEGIS). BMC Cancer. 2017;17(1):401. doi: 10.1186/s12885-0173386-2.

2. Birla R. Relatia boala de reflux gastroesofagian - esofag Barrett adenocarcinom de jonctiune esogastrica. In: Constantinoiu S, Cordos I, Ciuce C, Scripcariu V, editors. Tratat de patologie si chirurgie esofagiana. Bucuresti: Editura Academiei Romane; 2017. p. $724-730$.

3. Price TN, Nichols FC, Harmsen WS, Allen MS, Cassivi SD, Wigle DA et al. A comprehensive review of anastomotic technique in 432 esophagectomies. Ann Thorac Surg. 2013;95(4):1154-60.

4. The National Comprehensive Cancer Network $(\mathrm{NCCN} \otimes)$. NCCN Guidelines Version 1. Esophageal and Esogastric Junction Cancers. 2018. p-54-80.

5. Cox SJ, O'Cathail SM, Coles B, Crosby T, Mukherjee S. Update on Neoadjuvant Regimens for Patients with Operable Oesophageal/ Gastrooesophageal Junction Adenocarcinomas and Squamous Cell Carcinomas. Curr Oncol Rep. 2017;19(1):7. doi: 10.1007/s11912017-0559-8.

6. Buas MF, Vaughan T. Epidemiology and risk factors for gastroesophageal junction tumors: understanding the rising incidence of this disease. Semin Radiat Oncol. 2013;23(1):3-9. doi: 10.1016/ j.semradonc.2012.09.008

7. Zhao Q, Li Y, Wang J, Zhang J, Qiao X, Tan B, et al.Concurrent Neoadjuvant Chemoradiotherapy for Siewert II and III Adenocarcinoma at Gastroesophageal Junction. Am J Med Sci. 2015:349(6): 472-6.

8. Li G, Zhang Z, Ma X, Zhu J, Cai G. Postoperative chemoradiotherapy combined with epirubicin-based triplet chemotherapy for locally advanced adenocarcinoma of the stomach or gastroesophageal junction. PLoS One. 2013;8(1):e54233. doi: 10.1371/ journal.pone.0054233. Epub 2013 Jan 25.

9. Sjoquist KM, Burmeister BH, Smithers BM, Zalcberg JR, Simes RJ, Barbour A, et al. Survival after neoadjuvant chemotherapy or chemoradiotherapy for resectable oesophageal carcinoma: an updated meta-analysis. Lancet Oncol. 2011;12(7):681-92.

10. Moorcraft SY, Smyth EC, Cunningham D. Adjuvant or neoadjuvant therapy for operable esophagogastric cancer? Gastric Cancer. 2015;18(1):1-10. doi: 10.1007/s10120-014-0356-0. Epub 2014 Mar 18.

11. Oppedijk $V$, van der Gaast $A$, van Lanschot JJ, van Hagen $P$, van 0 s $\mathrm{R}$, van Rij CM, et al. Patterns of recurrence after surgery alone versus preoperative chemoradiotherapy and surgery in the CROSS trials. J Clin Oncol. 2014;32(5):385-91. doi: 10.1200/JC0.2013.51. 2186. Epub 2014 Jan 13.

12. Fields RC, Strong VE, Gönen M, Goodman KA, Rizk NP, Kelsen DP, et al. Recurrence and survival after pathologic complete response to preoperative therapy followed by surgery for gastric or gastro- oesophageal adenocarcinoma. Br J Cancer. 2011;104(12):1840-7. doi: 10.1038/bjc.2011.175. Epub 2011 May 24.

13. Donahue JM, Nichols FC, Li Z, Schomas DA, Allen MS, Cassivi SD, et al. Complete pathologic response after neoadjuvant chemoradiotherapy for esophageal cancer is associated with enhanced survival. Ann Thorac Surg. 2009;87(2):392-8; discussion 398-9. doi: 10.1016/j.athoracsur.2008.11.001.

14. Macdonald JS, Smalley SR, Benedetti J, Hundahl SA, Estes NC, Stemmermann GN, et al. Chemoradiotherapy after surgery compared with surgery alone for adenocarcinoma of the stomach or gastroesophageal junction. N Engl J Med. 2001;345(10):725-30.

15. Smalley SR, Benedetti JK, Haller DG, Hundahl SA, Estes NC, Ajani JA, et al. Updated analysis of SWOG-directed Intergroup Study 0116: a phase III trial of adjuvant radiochemotherapy versus observation after curative gastric cancer resection. J Clin Oncol. 2012;30(19):2327-33. doi: 10.1200/JC0.2011.36.7136. Epub 2012 May 14.

16. Ott K, Bader FG, Lordick F, Feith M, Bartels H, Siewert JR. Surgical factors influence the outcome after Ivor-Lewis esophagectomy with intrathoracic anastomosis for adenocarcinoma of the esophagogastric junction: a consecutive series of 240 patients at an experienced center. Ann Surg Oncol. 2009:16(4):1017-25.

17. Cunningham D, Allum WH, Stenning SP, Thompson JN, Van de Velde $\mathrm{CJ}$, Nicolson M, et al. Perioperative chemotherapy versus surgery alone for resectable gastroesophageal cancer. N Engl J Med. 2006; 355(1):11-20.

18. Stahl M, Walz MK, Stuschke M, Lehmann N, Meyer HJ, RieraKnorrenschild J, et al. Phase III comparison of preoperative chemotherapy compared with chemoradiotherapy in patients with locally advanced adenocarcinoma of the esophagogastric junction. J Clin Oncol. 2009;27(6):851-6. doi: 10.1200/JC0.2008.17.0506. Epub 2009 Jan 12.

19. Urba SG, Orringer MB, Turrisi A, lannettoni M, Forastiere A, Strawderman M. Randomized trial of preoperative chemoradiation versus surgery alone in patients with locoregional esophageal carcinoma. J Clin Oncol. 2001;19(2):305-13.

20. Burmeister BH, Smithers BM, Gebski V, Fitzgerald L, Simes RJ, Devitt $P$, et al. Surgery alone versus chemoradiotherapy followed by surgery for resectable cancer of the oesophagus: $A$ randomised controlled phase III trial. Lancet Oncol. 2005;6(9):659-68.

21. van Hagen $P$, Hulshof MC, van Lanschot JJ, Steyerberg EW, van Berge Henegouwen MI, Wijnhoven BP et al. CROSS Group. Preoperative chemoradiotherapy for esophageal or junctional cancer. N Engl J Med. 2012;366(22):2074-84.

22. Knab LM, Belotte J, Munshi HG, Bentrem DJ. Comparative effectiveness in esophagogastric cancer. Cancer Treat Res. 2015;164:121-42. doi: 10.1007/978-3-319-12553-4_8.

23. Moorcraft SY, Smyth EC, Cunningham D. Adjuvant or neoadjuvant therapy for operable esophagogastric cancer? Gastric Cancer. 2015; 18(1):1-10.

24. Shapiro J, van Lanschot JJB, Hulshof MCCM, van Hagen P, van Berge Henegouwen MI, Wijnhoven BPL, et al. Neoadjuvant chemoradiotherapy plus surgery versus surgery alone for oesophageal or junctional cancer (CROSS): long-term results of a randomised controlled trial. Lancet Oncol. 2015;16(9):1090-1098. doi: 10.1016/S1470-2045(15)00040-6. Epub 2015 Aug 5.

25. Constantinoiu S, Birla R, Copca N, Iosif C. Adenocarcinomul de jonctiune esogastrica. Bucuresti: Editura Almatea; 2008. p. 80-120.

26. Bekkar S, Gronnier C, Messager M, Robb WB, Piessen G, Mariette C. The impact of preoperative radiochemotherapy on survival in advanced esophagogastric junction signet ring cell adenocarcinoma. Ann Thorac Surg. 2014 Jan;97(1):303-10.

27. Constantinoiu S, Ciuce C, et al. IA Chirurgie generala. In: Popescu I, editor. Tratat de Chirurgie, Vol VIII. Bucuresti: Editura Academiei Romane; 2010. Cap.42. 